\title{
Article \\ Responses of Polyamine-Metabolic Genes to Polyamines and Plant Stress Hormones in Arabidopsis Seedlings
}

\author{
Yusaku Yariuchi ${ }^{1}$, Takashi Okamoto ${ }^{1}$, Yoshiteru Noutoshi ${ }^{2}$ and Taku Takahashi ${ }^{1, *}$ \\ 1 Graduate School of Natural Science and Technology, Okayama University, Okayama 700-8530, Japan; \\ yarioka@s.okayama-u.ac.jp (Y.Y.); takashi_okamoto@cc.okayama-u.ac.jp (T.O.) \\ 2 Graduate School of Environmental and Life Science, Okayama University, Okayama 700-8530, Japan; \\ noutoshi@cc.okayama-u.ac.jp \\ * Correspondence: perfect@cc.okayama-u.ac.jp; Tel.: +81-86-251-7858
}

Citation: Yariuchi, Y.; Okamoto, T.; Noutoshi, Y.; Takahashi, T. Responses of Polyamine-Metabolic Genes to Polyamines and Plant Stress Hormones in Arabidopsis Seedlings. Cells 2021, 10, 3283. https://doi.org/ $10.3390 /$ cells10123283

Academic Editors: Ruben Alcazar, Stanislaw Karpinski and Keqiang Wu

Received: 26 September 2021 Accepted: 23 November 2021 Published: 24 November 2021

Publisher's Note: MDPI stays neutral with regard to jurisdictional claims in published maps and institutional affiliations.

Copyright: (c) 2021 by the authors. Licensee MDPI, Basel, Switzerland. This article is an open access article distributed under the terms and conditions of the Creative Commons Attribution (CC BY) license (https:// creativecommons.org/licenses/by/ $4.0 /)$.

\begin{abstract}
In plants, many of the enzymes in polyamine metabolism are encoded by multiple genes, whose expressions are differentially regulated under different physiological conditions. For comprehensive understanding of their regulation during the seedling growth stage, we examined the expression of polyamine metabolic genes in response to polyamines and stress-related plant hormones in Arabidopsis thaliana. While confirming previous findings such as induction of many of the genes by abscisic acid, induction of arginase genes and a copper amine oxidase gene, CuAO 3 , by methyl jasmonate, that of an arginine decarboxylase gene, $A D C 2$, and a spermine synthase gene, SPMS, by salicylic acid, and negative feedback regulation of thermospermine biosynthetic genes by thermospermine, our results showed that expressions of most of the genes are not responsive to exogenous polyamines. We thus examined expression of OsPAO6, which encodes an apoplastic polyamine oxidase and is strongly induced by polyamines in rice, by using the promoter-GUS fusion in transgenic Arabidopsis seedlings. The GUS activity was increased by treatment with methyl jasmonate but neither by polyamines nor by other plant hormones, suggesting a difference in the response to polyamines between Arabidopsis and rice. Our results provide a framework to study regulatory modules directing expression of each polyamine metabolic gene.
\end{abstract}

Keywords: abscisic acid; Arabidopsis; jasmonate; polyamine metabolism; salicylic acid

\section{Introduction}

Polyamines function in various aspects of plant development and stress responses. In land plants, many of the enzymes in polyamine biosynthetic and catabolic pathways are encoded by multiple genes, which show differential expression patterns under different physiological conditions and in different tissues. In Arabidopsis thaliana, there are two genes encoding arginine decarboxylase (ADC), a key enzyme for putrescine biosynthesis, $A D C 1$ and $A D C 2$. $A D C 1$ shows a constitutive expression and is also responsive to cold and bacterial pathogen infection, while $A D C 2$ is upregulated by abiotic stresses such as salt, drought, cold, and wounding [1-7]. Agmatine produced by ADC is converted to putrescine by two sequential enzymes of agmatine iminohydrolase (AIH) [8] and Ncarbamoylputrescine amidohydrolase (CPA) [9] or in a single step mediated by agmatinase. The Arabidopsis genome has two genes encoding a dual functional arginase/agmatinase, $A R G A H 1$ and $A R G A H 2$. Expression of both genes is co-regulated with $A D C 2$ in response to abscisic acid (ABA), methyl jasmonate (MeJA), drought, cold, and high salinity, suggesting that the agmatinase pathway may be a major contributor to putrescine biosynthesis under stress conditions [10]. ABA also upregulates the expression of a gene for spermine synthase, SPMS [11]. On the other hand, ACL5 encoding thermospermine synthase is specifically expressed in xylem precursor cells and plays a key role in repressing xylem differentiation. ACL5 expression is upregulated by auxin and downregulated by thermospermine [12]. Biosynthesis of spermidine, spermine, and thermospermine requires 
decarboxylated S-adenosyl methionine as an aminopropyl donor, which is supplied by S-adenosyl methionine decarboxylase (SAMDC/AdoMetDC). Among four genes encoding SAMDC/AdoMetDC in Arabidopsis, SAMDC1, SAMDC2, and SAMDC3, contain conserved upstream open-reading frames (uORFs) within the $5^{\prime}$ leader region of each mRNA. The UORFs of $S A M D C 1$ have been shown to play a regulatory role in the translation of the main ORF in response to cellular polyamine levels [13]. A recent study has reported that expression of $A D C 1, S A M D C 2, S A M D C 4$, and two genes for spermidine synthase, SPDS1 and $S P D S 2$, are drastically induced during cytokinin-induced direct shoot regeneration from root primordia, suggesting the importance of spermidine in plant regeneration [14].

Plant polyamine catabolism is mediated by copper amine oxidase ( $\mathrm{CuAO}$ ), which mainly oxidizes putrescine, and polyamine oxidase (PAO). These amine oxidases participate in important physiological processes through the production of hydrogen peroxide [15-18]. Arabidopsis contains five genes for $\mathrm{PAO}$ and eight genes for $\mathrm{CuAO}$. $\mathrm{CuAO} \gamma \mathrm{I}$ and $\mathrm{CuAO \zeta}$, which encode an extracellular and peroxisomal $\mathrm{CuAO}$, respectively, are upregulated by ABA and salicylic acid (SA), while $C u A O \alpha 3$ encoding a peroxisomal enzyme shows a marked induction by methyl jasmonate (MeJA) and wounding [19]. Another study revealed a transient increase for several hours in the expression of $C u A O \alpha 2, C u A O \alpha 3, C u A O \gamma 1$,

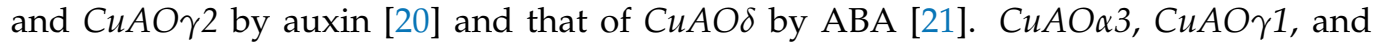
$\mathrm{CuAO} \gamma 2$ were also shown to be upregulated by putrescine [20]. On the other hand, PAO1, PAO3, and PAO4 expressions are increased by treatment with salicylic acid for $24 \mathrm{~h}[22,23]$. PAO3 expression is also responsive to ABA and MeJA [22]. A transgenic study revealed that overproduction of thermospermine by ectopic expression of ACL5 results in an increased expression of $P A O 1, P A O 3$, and $C u A O \beta$ [24]. Most land plants, except the superasterid clade and a part of the superrosid clade, including Arabidopsis in eudicots, contain extracellular PAOs [25], and they may play a protective role against pathogens or wounding by generating hydrogen peroxide and amino aldehydes [15-18]. In maize, extracellular PAO activity has been shown to be involved in peroxidase-mediated wall stiffening events during wound healing [16]. Expressions of the genes encoding extracellular PAOs in rice were shown to be induced by polyamines [26] and MeJA [27].

Taken together, these studies indicate that different genes for the same metabolic functions play a role in different physiological or environmental conditions. A genomewide transcriptome analysis of polyamine metabolic genes in tomato leaves reveals a more pronounced role of polyamines in cold stress acclimation than in heat stress tolerance [28]. Here, towards comprehensively understanding the mechanism of differential regulation of polyamine metabolic genes in Arabidopsis, we focused on the response of these genes to stress-related plant hormones and polyamines during the seedling stage.

\section{Materials and Methods}

\subsection{Chemicals}

All polyamines used in this study were hydrochloride salts. Putrescine, spermidine, and spermine were purchased from Nakalai Tesque (Kyoto, Japan). Thermospermine was purchased from Santa Cruz Biotechnology (Santa Cruz, CA, USA).

\subsection{Plant Growth Conditions}

The Columbia (Col-0) accession of Arabidopsis thaliana was used as wild type. Seeds were surface-sterilized with bleach solution containing $0.01 \%(w / v)$ Triton X-100 for 3 min and rinsed three times in sterile water. Approximately 30 seeds were sown in $25 \mathrm{~mL}$ of half-strength MS (Wako, Tokyo, Japan) liquid media at pH 5.7 containing 1\% sucrose and cultured for 7 days on rotary shakers at $22{ }^{\circ} \mathrm{C}$ under $16 \mathrm{~h}$ light $/ 8 \mathrm{~h}$ dark conditions. For treatment with polyamines or plant hormones, seedlings were further incubated in the presence of each compound for $6 \mathrm{~h}$ unless otherwise stated. Polyamine concentrations were chosen based on our preliminary results on minimum concentration levels toxic to the seedling growth and previous studies [29]. 


\subsection{RNA Extraction and Expression Analyses}

Total RNA was extracted from whole seedlings by the SDS-phenol method followed by $\mathrm{LiCl}$ precipitation [30] and reverse-transcribed using a PrimeScript RT reagent kit (Takara, Kyoto, Japan) with the oligo dT primer. PCR reactions were performed using a KAPA SYBR FAST qPCR kit (KAPA Biosystems, Woburn, MA, USA) and the Thermal Cycler Dice TP760 (Takara) with gene-specific primers (Supplementary Table S1). ACTIN8 (At1g49240) was used to normalize the reaction. UBQ10 (At4g05320) was used as another reference gene and confirmed to show no significant difference from ACT8 in the response to the chemicals examined (Tables 1 and 2). For each plant treatment, RNA was prepared three times, and each sample was duplicated in PCR reactions.

Table 1. Effect of polyamine treatment on polyamine metabolic genes.

\begin{tabular}{|c|c|c|c|c|c|}
\hline \multirow{2}{*}{ Gene Name } & \multirow{2}{*}{ Gene ID } & \multicolumn{4}{|c|}{ Treatment (6 h) } \\
\hline & & Put $5 \mathrm{mM}$ & Spd $1 \mathrm{mM}$ & Spm $0.5 \mathrm{mM}$ & Tspm $0.1 \mathrm{mM}$ \\
\hline$A D C 1$ & AT2G16500 & 1.25 & 0.50 & 1.17 & 1.30 \\
\hline$A D C 2$ & AT4G34710 & $5.90 *$ & 0.14 * & 1.07 & 0.60 \\
\hline ARGAH1 & AT4G08900 & 1.46 & 1.04 & 1.36 & 0.74 \\
\hline$A R G A H 2$ & AT4G08870 & 1.51 & 1.10 & 1.04 & 1.18 \\
\hline AIH & AT5G08170 & 1.89 & 1.13 & 1.21 & 1.27 \\
\hline CPA & AT2G27450 & 1.33 & 1.20 & 1.21 & 0.89 \\
\hline SPDS1 & AT1G23820 & 1.77 & 1.04 & 1.01 & 1.61 \\
\hline SPDS2 & AT1G70310 & 1.17 & 1.85 & 1.20 & 0.91 \\
\hline SPMS & AT5G53120 & 1.49 & 1.90 & 1.49 & 0.85 \\
\hline ACL5 & AT5G19530 & 1.10 & 2.33 & 1.34 & $0.28^{* * *}$ \\
\hline SAMDC1 & AT3G02470 & 1.14 & 0.96 & 1.17 & 0.94 \\
\hline SAMDC2 & AT5G15950 & 1.63 & 1.42 & 1.30 & 0.87 \\
\hline SAMDC3 & AT3G25570 & 1.06 & 1.43 & 1.26 & 0.74 \\
\hline SAMDC4/BUD2 & AT5G18930 & 0.64 & 1.63 & 0.65 & $0.19^{* *}$ \\
\hline PAO1 & AT5G13700 & 1.54 & 2.13 & 1.22 & 0.69 \\
\hline PAO2 & AT2G43020 & 2.30 & $3.88 *$ & 1.38 & 0.90 \\
\hline PAO3 & AT3G59050 & 1.49 & 2.35 & 1.28 & 1.04 \\
\hline PAO4 & AT1G65840 & 0.58 & 2.54 & 1.34 & 1.38 \\
\hline PAO5 & AT4G29720 & 1.34 & 2.25 & 1.05 & 1.03 \\
\hline СuAO $\alpha 1$ & AT1G31670 & N.D. & N.D. & N.D. & N.D. \\
\hline $\mathrm{CuAO \alpha 2}$ & AT1G31690 & 0.25 & 1.88 & 1.15 & 0.91 \\
\hline $\mathrm{CuAO \alpha 3/CuAO2}$ & AT1G31710 & 1.13 & 1.36 & 1.26 & 0.78 \\
\hline СиАОß/ATAO1 & AT4G14940 & 0.48 & 1.39 & 1.45 & 0.61 \\
\hline СuAOү1/СuAO1 & AT1G62810 & 1.40 & 1.10 & 0.91 & 1.09 \\
\hline CuAOr 2 & AT3G43670 & 0.69 & 0.95 & 1.36 & 0.87 \\
\hline$C u A O \delta$ & AT4G12270 & 0.90 & 1.34 & 2.40 & 0.35 \\
\hline СиАОЪ/СuAOЗ & AT2G42490 & 1.13 & 1.49 & 1.79 & 0.79 \\
\hline UBQ10 & AT4G05320 & 0.98 & 0.95 & 0.94 & 0.92 \\
\hline
\end{tabular}

Expression levels of three biological replicates each with duplicated PCR reactions are presented relative to the mock control. Significantly increased and decreased values evaluated by Student's $t$-test are shaded with pale $\left({ }^{*} p<0.05\right)$ or dark $\left({ }^{* *} p<0.01\right)$ green and red colors, respectively. N.D., not detected.

\subsection{T-DNA Construction and Plant Transformation}

For the OsPAO6 promoter-driven expression of the GUS reporter gene, a 990-bp genomic fragment upstream from the 1st exon of OsPAO6 was amplified by PCR with primers OsPAO6pro-FCl (5'-ATCGA TGAAG CTGCC ATCGC CAG-3') and OsPAO6proRBm (5'-GGATC CCTTC TTGGC ACGAG AATG-3'), cloned into a pGEM-T Easy vector (Promega, WI, USA), and then transferred to ClaI-BamHI sites of Ti-plasmid vector pBI101 (Clontech, CA, USA). The resulting Ti plasmid construct was introduced into Agrobacterium tumefaciens $\mathrm{C} 58 \mathrm{C} 1$ by electroporation. Arabidopsis plants were transformed using the floral dip method [31]. Transgenic lines were selected on kanamycin and confirmed by PCR using the T-DNA-specific primers, pBI-ClaF (5'-GTCGC TACTG ATTAC GG-3') and GUS-R (5'-TCACG GGTTG GGGTT TCTAC-3'). Three independent homozygous lines 
carrying single copy of the transgene were further selected based on the segregation ratio of kanamycin-resistant plants in subsequent generations.

Table 2. Effect of plant hormone treatment on polyamine metabolic genes.

\begin{tabular}{|c|c|c|c|c|c|c|c|}
\hline \multirow{2}{*}{ Gene Name } & \multirow{2}{*}{ Gene ID } & \multicolumn{6}{|c|}{ Treatment $(6 \mathrm{~h})$} \\
\hline & & IAA $10 \mu \mathrm{M}$ & Kinetin $5 \mu \mathrm{M}$ & ABA $1 \mu \mathrm{M}$ & ACC $10 \mu \mathrm{M}$ & MeJA $2 \mu \mathrm{M}$ & NaSA $1 \mathrm{mM}$ \\
\hline$A D C 1$ & AT2G16500 & 1.85 & 1.34 & 0.62 & 2.45 & 0.51 & 1.64 \\
\hline$A D C 2$ & AT4G34710 & $4.06^{*}$ & 1.19 & $8.01^{* *}$ & $27.28^{* *}$ & 0.96 & $26.91^{* *}$ \\
\hline ARGAH1 & AT4G08900 & 1.13 & 1.08 & $3.95^{*}$ & 2.09 & $5.94 *$ & 1.13 \\
\hline ARGAH2 & AT4G08870 & 2.16 & 1.11 & $9.78^{* *}$ & 2.31 & $31.78^{* *}$ & 0.97 \\
\hline AIH & AT5G08170 & 1.66 & 0.59 & $5.24 *$ & 1.34 & 1.65 & $3.23 *$ \\
\hline$C P A$ & AT2G27450 & 1.74 & 0.74 & 3.84 * & 1.82 & 1.23 & 1.49 \\
\hline SPDS1 & AT1G23820 & 1.14 & 1.72 & 1.55 & 1.36 & 1.07 & 1.40 \\
\hline SPDS2 & AT1G70310 & 1.85 & 1.43 & $2.81^{*}$ & 1.07 & 0.89 & 1.15 \\
\hline SPMS & AT5G53120 & 1.70 & 0.90 & $20.25^{* *}$ & 1.21 & 1.11 & $13.83 * *$ \\
\hline ACL5 & AT5G19530 & 3.46 * & 2.34 & 1.10 & 1.01 & 1.49 & 0.72 \\
\hline SAMDC1 & АT3G02470 & 0.88 & 0.58 & $2.47^{*}$ & 1.37 & 0.81 & 2.66 \\
\hline$S A M D C 2$ & AT5G15950 & 1.11 & 0.71 & $9.00^{* *}$ & 0.83 & 0.77 & 0.14 \\
\hline SAMDC3 & AT3G25570 & 2.08 & 0.77 & 1.39 & 1.47 & 1.20 & 0.85 \\
\hline SAMDC4/BUD2 & AT5G18930 & 2.95 * & 0.92 & 2.15 & 1.41 & 0.91 & 0.40 \\
\hline PAO1 & AT5G13700 & 3.51 * & 1.09 & $5.28 *$ & 2.73 & 0.73 & $8.00 * *$ \\
\hline PAO2 & AT2G43020 & 0.72 & 1.05 & $3.16^{*}$ & 1.71 & 1.16 & 1.25 \\
\hline PAO3 & АT3G59050 & 2.38 * & 0.83 & 2.39 * & 2.10 & $2.46^{*}$ & 1.11 \\
\hline PAO4 & AT1G65840 & 1.04 & 0.56 & 3.25 * & 1.14 & 0.66 & 0.86 \\
\hline PAO5 & AT4G29720 & $2.87^{*}$ & 1.52 & 2.03 & 1.73 & 1.88 & 0.33 \\
\hline CuAO $\alpha 1$ & AT1G31670 & N.D. & N.D. & N.D. & N.D. & N.D. & N.D. \\
\hline 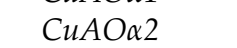 & AT1G31690 & 0.19 * & 1.58 & 1.45 & $0.03^{* *}$ & 1.17 & $0.11^{* * *}$ \\
\hline СиАО $3 /$ СuAO2 & AT1G31710 & 0.32 * & 1.61 & 0.89 & 0.88 & 3.84 * & 0.30 * \\
\hline СUAOB/ATAO1 & AT4G14940 & 0.71 & 1.52 & 1.46 & 1.60 & 0.08 & 0.71 \\
\hline СиАОү1/СuAO1 & AT1G62810 & 1.38 & 0.70 & $10.10^{* *}$ & 1.57 & 0.79 & 0.74 \\
\hline $\mathrm{CuAO \gamma} 2$ & AT3G43670 & 1.01 & 0.54 & 1.51 & 1.00 & 0.88 & 0.55 * \\
\hline СuAO $\delta$ & AT4G12270 & 1.26 & 0.16 & $4.72 *$ & 0.6 & 0.77 & 1.74 \\
\hline СиАОЪ/СИАОЗ & AT2G42490 & 0.84 & 0.76 & 1.91 & 1.91 & 1.22 & 2.45 \\
\hline UBQ10 & AT4G05320 & 1.02 & 0.94 & 1.11 & 0.96 & 0.94 & 0.92 \\
\hline
\end{tabular}

Expression levels of three biological replicates each with duplicated PCR reactions are presented relative to the mock control. Significantly increased and decreased values evaluated by Student's $t$-test are shaded with pale $\left({ }^{*} p<0.05\right)$ or dark $\left({ }^{* *} p<0.01\right)$ green and red colors, respectively. N.D., not detected.

\subsection{GUS Assays}

Fluorometric assay of the bacterial $\beta$-glucuronidase (GUS) activity was performed as described previously [32]. The fluorescence was measured with an RF-5300PC spectrofluorophotometer (Shimadzu, Kyoto, Japan). Total protein content was measured by using the Bradford assay (BioRad, Hercules, CA, USA).

\subsection{Statistics}

All statistical tests were performed using Student's $t$-test $\left({ }^{*} p<0.05,{ }^{* *} p<0.01\right)$.

\section{Results}

\subsection{Responses of Polyamine Metabolic Genes to Polyamines}

In this study, we examined expressions of all 27 genes directly involved in polyamine biosynthesis and degradation in 7-day-old seedlings of Arabidopsis grown in liquid media. Although we could not detect expression of $C u A O \alpha 1$ at the seedling stage, most of the genes showed no significant change in transcript levels after treatment for $6 \mathrm{~h}$ with $5 \mathrm{mM}$ putrescine, $1 \mathrm{mM}$ spermidine, and $0.5 \mathrm{mM}$ spermine or $0.1 \mathrm{mM}$ thermospermine (Table 1 ). The exceptions were $A D C 2, A C L 5, S A M D C 4 / B U D 2$, and PAO2. In agreement with previous studies [12,33], expressions of ACL5 and SAMDC4/BUSHY AND DWARF2 (BUD2), both of which are specifically expressed in the vasculature and involved in thermospermine 
biosynthesis, were reduced by thermospermine. PAO5 encoding thermospermine oxidase was not responsive to thermospermine. $A D C 2$ expression was reduced by spermidine but rather promoted by putrescine. Expression of $P A O 2$, which is mainly involved in spermidine oxidation, was upregulated by spermidine, but $P A O 3$, which also functions in spermidine oxidation, showed no significant response to spermidine.

\subsection{Responses of Polyamine Metabolic Genes to Plant Stress Hormones}

We next examined the response of these genes to stress-related plant hormones. Seedlings were incubated for $6 \mathrm{~h}$ with each hormone (Table 2). Treatment with an auxin, indole acetic acid (IAA), activated expression of not only ACL5 and SAMDC4/BUD2 but also $A D C 2, P A O 1, P A O 3$, and $P A O 5$. $C u A O \alpha 2$ and $C u A O \alpha 3$ were downregulated by IAA. No genes showed significant changes in response to kinetin under our experimental conditions. Treatment with ABA activated expression of 16 genes involved in the biosynthesis or catabolism of polyamines. The genes that showed no significant response to ABA

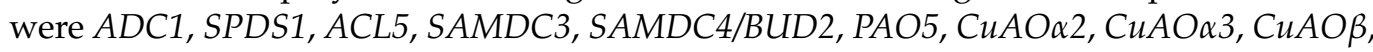
$\mathrm{C} u A O \gamma 2$, and $\mathrm{CuAO \zeta}$. Treatment with amino cyclopropane carboxylate (ACC) as a precursor of ethylene also upregulated expression of $A D C 2$ but downregulated expression of $C u A O \alpha 2$. Treatment with MeJA caused a drastic increase in the expression of ARGAH2 and a several-fold increase in the expression of $A R G A H 1$ and $C u A O \alpha 3$, as reported previously $[19,34]$, and also of $P A O 3$. The results also revealed that sodium salicylate (NaSA), which was used as the source of salicylic acid, upregulated expression of $A D C 2, A I H$, $S P M S, S A M D C 1$, and PAO1 but downregulated expression of $S A M D C 2, C u A O \alpha 2, C u A O \alpha 3$, and $\mathrm{CuAO \gamma} 2$.

Salicylic acid has been shown to be converted at the primary site of pathogen infection to methyl salicylate (MeSA), which in turn acts as a mobile signal and is again reversed at distant tissues to induce systemic acquired resistance [35]. We thus compared the responses of the above-described NaSA-responsive genes to sodium and methyl SA. Among the genes examined, $A D C 2$ showed the strongest induction after $6 \mathrm{~h}$ treatment with MeSA, while it also showed a more than twenty-fold increase in the transcript level after 6 and $24 \mathrm{~h}$ treatment with NaSA (Figure 1). AIH, SPMS, and PAO1 also showed increased transcript levels after $6 \mathrm{~h}$ treatment with MeSA but to a lesser degree than the treatment with NaSA (Figure 1). SAMDC1 responded slightly to NaSA but showed no significant response to MeSA (Figure 1). We also found that ARGH1 and ARGH2 transcript levels were upregulated after $24 \mathrm{~h}$ treatment with $\mathrm{NaSA}$, although these were not responsive to the $6 \mathrm{~h}$ treatment and were only slightly upregulated by treatment with MeSA (Figure 1). On the other hand, $S A M D C 2$ and $C u A O \alpha 3$, whose transcript levels were reduced by NaSA, showed no significant response to MeSA, while $C u A O \alpha 2$ and $C u A O \gamma 2$ showed reduced transcript levels after $6 \mathrm{~h}$ treatment with both MeSA and NaSA (Figure 1).

\subsection{OsPAO6 Promoter Is Responsive to MeJA in Arabidopsis}

Although all genes related to polyamine metabolism showed no significant change in the transcript level after spermine treatment in our experiments, we have recently found that expressions of OsPAO2 and OsPAO6, both of which encode extracellular enzymes, are drastically induced by spermine in rice [26]. We thus generated transgenic Arabidopsis lines with the GUS reporter gene under the control of a 1.1-kb promoter of OsPAO6 and examined whether the GUS expression is upregulated by spermine treatment or not. From more than 10 independent transgenic lines obtained, we selected three transgenic lines that showed a 3:1 ratio for kanamycin resistance in T2 generation and were established as homozygous T-DNA lines in the progeny. These lines showed no significant increase in the GUS activity after one-day treatment with putrescine, spermidine, and spermine (Figure 2A). We further examined the GUS activity after treatment with the above-examined plant hormones and found that MeJA had a strong inducing effect on the GUS activity while other hormones had no effect in these lines (Figure 2B). We also examined the effect of hydrogen peroxide, 
which is a product of polyamine oxidation, on the GUS activity but found no significant effect (Figure 2B).

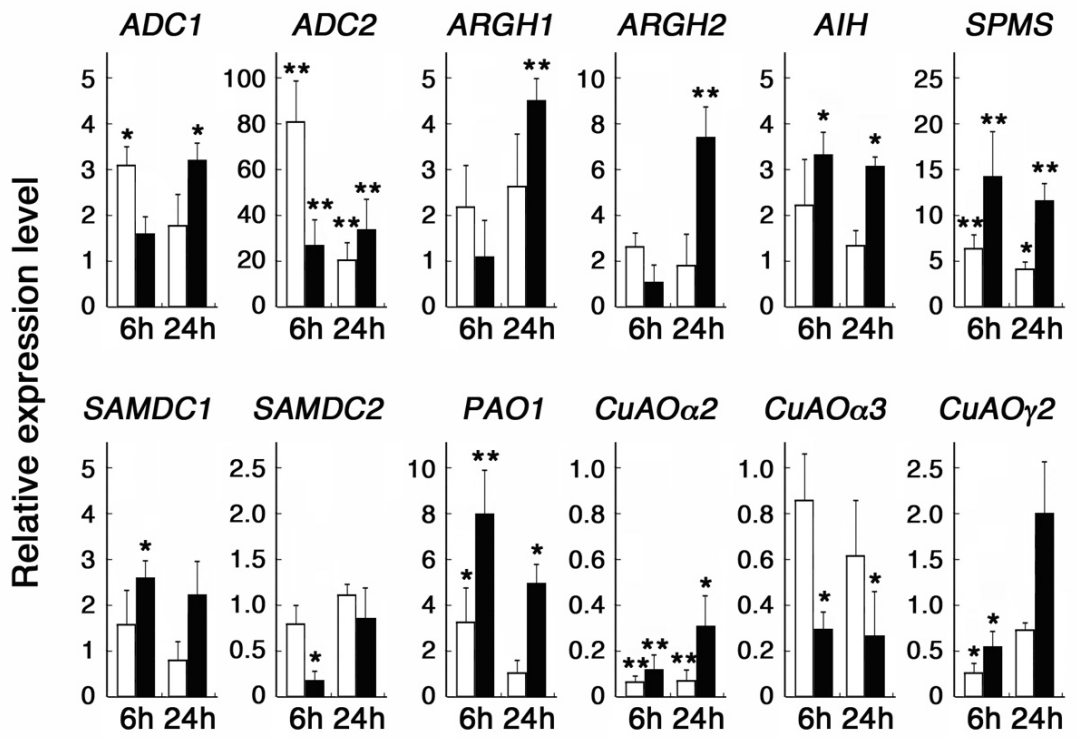

Figure 1. Effect of MeSA and NaSA on polyamine metabolic genes. Seven-day-old seedlings grown in liquid MS solution were further incubated with $1 \mathrm{mM}$ MeSA (white bars) or NaSA (black bars) for 6 and $24 \mathrm{~h}$. Transcript levels relative to the control of no SA treatment are shown. Data are expressed as mean values $\pm \mathrm{SD}(n=6)$. Asterisks indicate the statistical significance analyzed with Student's $t$-test, $\left({ }^{*} p<0.05, * * 00.01\right)$.

A

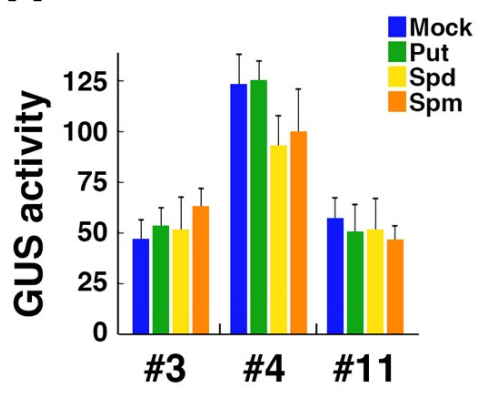

B

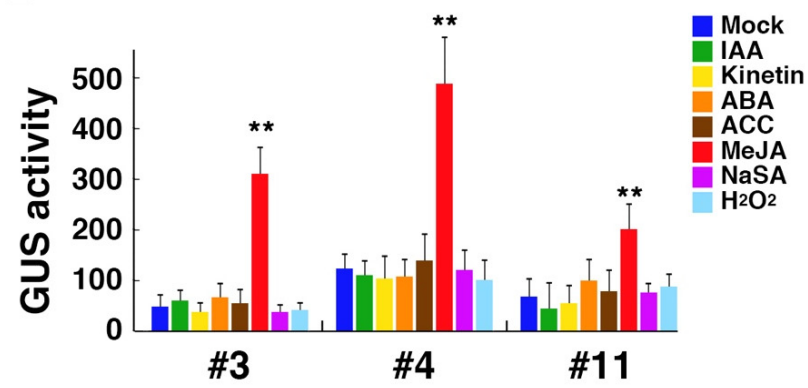

Figure 2. Effect of polyamines and stress-related plant hormones on the GUS activity in three transgenic Arabidopsis lines, \#3, \#4, and \#11, carrying the OsPAO6 promoter-GUS construct. (A) The relative GUS activity of 7-day-old seedlings after treatment with $5 \mathrm{mM}$ putrescine (Put), $1 \mathrm{mM}$ spermidine (Spd), or $0.5 \mathrm{mM}$ spermine (Spm) for $24 \mathrm{~h}$. (B) The relative GUS activity of 7-day-old seedlings after treatment with $10 \mu \mathrm{M}$ IAA, $5 \mu \mathrm{M}$ kinetin, $1 \mu \mathrm{M} \mathrm{ABA}, 10 \mu \mathrm{M}$ ACC, $2 \mu \mathrm{M}$ MeJA, 1 $\mathrm{mM} \mathrm{NaSA}$, or $0.3 \%$ hydrogen peroxide for $24 \mathrm{~h}$. Data are expressed as mean values $\pm \mathrm{SD}(\mathrm{n}=3)$. Asterisks indicate the statistical significance analyzed with Student's $t$-test $\left({ }^{* *} p<0.01\right)$.

\section{Discussion}

While much attention has been paid to the role of each polyamine in diverse plant physiological processes, regulatory mechanisms of transcriptional or post-transcriptional response of polyamine metabolic genes to polyamines or plant hormones have not been fully addressed. This prompted us to investigate the expression of these genes comprehensively in Arabidopsis seedlings. In this study, we focused on a fixed experimental condition in terms of duration and concentration of chemical treatments. Thus, the possibility should not be excluded that expression of some genes could show a fast and transient response to a certain polyamine or plant hormone, or also be responsive to even much lower concentration of polyamines. Our results revealed that the transcript levels of most of the genes 
involved in the synthesis and oxidative degradation of polyamines are not altered by $6 \mathrm{~h}$ treatment with putrescine, spermidine, spermine, and thermospermine. The exceptions are ADC2, PAO2, ACL5, and SAMDC4/BUD2, the latter two of which have been shown to be under negative feedback regulation by thermospermine [12,33]. Transcription of ACL5 is interfered with basic helix-loop-helix proteins of the SAC51 family whose translation is enhanced by thermospermine [36,37]. It remains to be examined whether SAMDC4/BUD2 is under the same regulation or not.

The $A D C 2$ transcript level was increased by putrescine but reduced by spermidine. Because the transcript levels of $A R G A H 1, A R G A H 2$, and CPA, the genes for the last step of putrescine biosynthesis, were not altered by putrescine, only $A D C 2$ may be regulated by positive feedback from putrescine or by the balance between putrescine and spermidine levels. Putrescine treatment has recently been shown to lead to local SA biosynthesis in Arabidopsis [38], while ADC2 expression was strongly induced by both NaSA and MeSA (Figure 1). It is thus possible that the $A D C 2$ induction is caused by putrescine-dependent $S A$ accumulation. A previous study using the GUS reporter gene has shown that the difference in the response to stresses between $A D C 1$ and $A D C 2$ is attributable to that of the promoter activity [6]. In an earlier work, a short uORF present in the $5^{\prime}$ leader of an $A D C$ mRNA in carnation has been suggested to act in the translational regulation of the main coding sequence [39]. A recent study revealed the presence of the conserved non-AUG-initiated uORF in the Arabidopsis $A D C 2$ mRNA [40]. Future investigations are expected to clarify whether the response of $A D C 2$ to polyamines and other stimuli involves uORF-mediated translational regulation or not.

Most of the genes involved in polyamine oxidation were not responsive to exogenous polyamines in Arabidopsis seedlings. This suggests no tight correlation between cellular polyamine concentrations and regulation of polyamine-catabolic genes. Considering the toxic effect of the catalytic products of polyamine oxidation such as hydrogen peroxide and amino aldehydes, it is reasonable that expressions of these genes are not altered drastically but finely tuned depending upon physiological conditions. However, a previous study has revealed that expressions of PAO1, PAO3, and PAO5 are slightly increased by thermospermine and spermine [24]. Another study has detected an increase in expressions of $\mathrm{CuAO \alpha 3}, \mathrm{CuAO \gamma}$, and $\mathrm{CuAO} \gamma 2$ by putrescine, although their time courses of induction and recovery are not the same [20]. In tomato, which also lacks extracellular PAOs, expressions of SIPAO2, SIPAO3, and SIPAO4, which may be orthologous to PAO2, $P A O 3$, and $P A O 4$ of Arabidopsis, respectively, are induced by polyamines [41]. The difference of the responses observed between studies might be due to different experimental conditions including the duration of chemical treatment and growth media. PAO2, PAO3, and PAO4 contain conserved uORFs, suggesting again the involvement of translational regulation in polyamine metabolism. The GUS reporter activity under the control of the CaMV 35S promoter fused with the $5^{\prime}$ leader region of $P A O 2$ has been shown to be induced by polyamines in transgenic Arabidopsis seedlings [42,43].

Expressions of OsPAO2 and OsPAO6, encoding extracellular PAOs in rice, are strongly induced by polyamines [26,27]. The $5^{\prime}$ leaders of these genes have no conserved uORFs [44]. The OsPAO6 promoter-GUS reporter gene showed no response to polyamines in transgenic Arabidopsis seedlings, while it was responsive to MeJA, indicating that the response of the OsPAO6 promoter to polyamines is uncoupled from that to MeJA. This suggests a difference in transcriptional regulation of $P A O$ genes between rice and Arabidopsis, although it remains to be determined whether this reporter construct responds to polyamines in rice or not. No response in Arabidopsis might also reflect the absence of apoplastic PAOs in Arabidopsis. It is possible that the response to exogenously supplied polyamines in rice involves their catalytic products generated by apoplastic PAOs. More detailed and comparative studies of the OsPAO6 promoter in rice and Arabidopsis will be needed to elucidate the precise molecular mechanism at the transcriptional level.

On the other hand, the results on the response to plant hormones confirmed that most of the genes examined were upregulated by ABA. However, except $C u A O \gamma 1$ encod- 
ing an apoplastic enzyme implicated in ABA-induced nitric oxide production [45] and $\mathrm{C} u A O \delta$, which encodes a putative vacuolar enzyme implicated in ABA-induced stomatal closure [21], genes for $\mathrm{CuAOs}$ showed no significant response to ABA. Although $\mathrm{CuAO \zeta}$ induction by $A B A$ was previously reported [19], the only slight increase was detected under our experimental condition. Taken together with the result that all PAO genes except PAO5 are upregulated by ABA, polyamine metabolism seems to be generally directed towards increasing intracellular accumulation of putrescine in the response to ABA. Many studies have revealed that putrescine levels are drastically increased by potassium deficiency [46], which also stimulates biosynthesis, accumulation, and transport of ABA [47,48].

The degree and time course of the response to NaSA and MeSA were different depending upon genes. Among other genes which generally responded more to NaSA than to MeSA, $A D C 2$ showed the highest fold induction at $6 \mathrm{~h}$ treatment with MeSA (Figure 1), suggesting different modes of action between NaSA and MeSA on $A D C 2$ expression. Increased expressions of $A D C 1, A D C 2, S A M D C 1, S P M S$, and PAO1 by $24 \mathrm{~h}$ treatment with $\mathrm{NaSA}$ are consistent with a recent study that showed a connection between SA signaling and polyamine metabolism [23]. The study also revealed that SA induces putrescine accumulation both in whole and apoplastic extracts. SA has also been shown to activate $A D C$ and ornithine decarboxylase gene expression in in maize, tobacco, and tomato [49-51]. The putrescine accumulation might be explained in part by the reduction in $S A M D C 2, C u A O \alpha 2$, $\mathrm{C} u A O \alpha 3$, and $\mathrm{CuAO \gamma} 2$ detected at $6 \mathrm{~h}$ treatment with NaSA. Expressions of $A R G H 1$ and $A R G H 2$ were not altered at $6 \mathrm{~h}$ treatment with NaSA but increased at $24 \mathrm{~h}$, suggesting the involvement of additional factors in their regulation. We further found that treatment with ACC drastically induces $A D C 2$ expression but decreases $C u A O \alpha 2$ expression. This may be in line with previous studies showing that ethylene enhances putrescine accumulation in some plants including rice [52] and that the $A D C 2$ promoter activity is reduced in an ethylene insensitive etr1 mutant [6]. On the other hand, putrescine or polyamines are known to suppress ethylene production in many plant species. Contrasting regulations of $A D C 2$ and $C u A O \alpha 2$ might be critical for the crosstalk between ethylene and polyamine metabolism. Overexpression of $A D C 2$ results in the accumulation of high levels of putrescine with no effect on spermidine and spermine contents and also affects gibberellin biosynthesis [53]. Moreover, $A D C 2$ expression was shown to be induced transiently by $2 \mathrm{~h}$ treatment with MeJA [4], although we detected no change after $6 \mathrm{~h}$ treatment (Table 2). Taken altogether, $A D C 2$ may serve as a hub connecting diverse functions of different plant hormones with putrescine.

Supplementary Materials: The following are available online at https://www.mdpi.com/article/ 10.3390/cells10123283/s1, Table S1: Primer sequences used for qRT-PCR.

Author Contributions: Conceptualization, Y.Y. and T.T.; methodology, Y.N. and T.T.; validation, Y.Y., T.O., Y.N. and T.T.; investigation, Y.Y. and T.O.; data curation, Y.Y., T.O., Y.N. and T.T.; writingoriginal draft preparation, Y.Y. and T.T.; writing-review and editing, Y.N.; visualization, Y.Y. and T.T.; funding acquisition, T.T. All authors have read and agreed to the published version of the manuscript.

Funding: This work was supported in part by the Japan Society for the Promotion of Science (JSPS) Grants-in-Aid for Scientific Research (Nos. 19K06724) to T.T.

Institutional Review Board Statement: Not applicable.

Informed Consent Statement: Not applicable.

Acknowledgments: This work is in memory of Antonio F. Tiburcio, who pioneered and advanced plant polyamine research.

Conflicts of Interest: The authors declare no conflict of interest.

\section{References}

1. Cuevas, J.C.; López-Cobollo, R.; Alcázar, R.; Zarza, X.; Koncz, C.; Altabella, T.; Salinas, J.; Tiburcio, A.F.; Ferrando, A. Putrescine is involved in Arabidopsis freezing tolerance and cold acclimation by regulating ABA levels in response to low temperature. Plant Physiol. 2008, 148, 1094-1105. [CrossRef] [PubMed] 
2. Rossi, F.R.; Marina, M.; Pieckenstain, F.L. 2014 Role of Arginine decarboxylase (ADC) in Arabidopsis thaliana defense against the pathogenic bacterium Pseudomonas viridiflava. Plant Biol. 2015, 17, 831-839. [CrossRef]

3. Soyka, S.; Heyer, A.G. Arabidopsis knockout mutation of ADC2 gene reveals inducibility by osmotic stress. FEBS Lett. 1999, 458, 219-223. [CrossRef]

4. Perez-Amador, M.A.; Leon, J.; Green, P.J.; Carbonell, J. 2002 Induction of the arginine decarboxylase ADC2 gene provides evidence for the involvement of polyamines in the wound response in Arabidopsis. Plant Physiol. 2002, 130, 1454-1463. [CrossRef]

5. Armengaud, P.; Breitling, R.; Amtmann, A. The potassium-dependent transcriptome of Arabidopsis reveals a prominent role of jasmonic acid in nutrient signaling. Plant Physiol. 2004, 136, 2556-2576. [CrossRef] [PubMed]

6. Hummel, I.; Bourdais, G.; Gouesbet, G.; Couée, I.; Malmberg, R.L.; El Amrani, A. Differential gene expression of ARGININE DECARBOXYLASE ADC1 and ADC2 in Arabidopsis thaliana: Characterization of transcriptional regulation during seed germination and seedling development. New Phytol. 2004, 163, 519-531. [CrossRef]

7. Urano, K.; Yoshiba, Y.; Nanjo, T.; Ito, T.; Yamaguchi-Shinozaki, K.; Shinozaki, K. Arabidopsis stress-inducible gene for arginine decarboxylase AtADC2 is required for accumulation of putrescine in salt tolerance. Biochem. Biophys. Res. Commun. 2004, 313, 369-375. [CrossRef]

8. Janowitz, T.; Kneifel, H.; Piotrowski, M. Identification and characterization of plant agmatine iminohydrolase, the last missing link in polyamine biosynthesis of plants. FEBS Lett. 2003, 544, 258-261. [CrossRef]

9. Piotrowski, M.; Janowitz, T.; Kneifel, H. 2002 Plant C-N-hydrolases: Identification of a plant N-carbamoylputrescine amidohydrolase involved in polyamine biosynthesis. J. Biol. Chem. 2003, 278, 1708-1712. [CrossRef]

10. Patel, J.; Ariyaratne, M.; Ahmed, S.; Ge, L.; Phuntumart, V.; Kalinoski, A.; Morris, P.F. Dual functioning of plant arginases provides a third route for putrescine synthesis. Plant Sci. 2017, 262, 62-73. [CrossRef]

11. Hanzawa, Y.; Imai, A.; Michael, A.J.; Komeda, Y.; Takahashi, T. Characterization of the spermidine synthase-related gene family in Arabidopsis thaliana. FEBS Lett. 2002, 527, 176-180. [CrossRef]

12. Kakehi, J.-I.; Kuwashiro, Y.; Niitsu, M.; Takahashi, T. Thermospermine is required for stem elongation in Arabidopsis thaliana. Plant Cell Physiol. 2008, 49, 1342-1349. [CrossRef] [PubMed]

13. Hanfrey, C.; Elliott, K.A.; Franceschetti, M.; Mayer, M.J.; Illingworth, C.; Michael, A.J. A dual upstream open reading frame-based autoregulatory circuit controlling polyamine-responsive translation. J. Biol. Chem. 2005, 280, 39229-39237. [CrossRef] [PubMed]

14. Kaszler, N.; Benkő, P.; Bernula, D.; Szepesi, Á.; Fehér, A.; Gémes, K. Polyamine metabolism is involved in the direct regeneration of shoots from Arabidopsis lateral root primordia. Plants 2021, 10, 305. [CrossRef] [PubMed]

15. Cona, A.; Rea, G.; Angelini, R.; Federico, R.; Tavladoraki, P. Functions of amine oxidases in plant development and defense. Trends Plant Sci. 2006, 11, 80-88. [CrossRef]

16. Angelini, R.; Tisi, A.; Rea, G.; Chen, M.M.; Botta, M.; Federico, R.; Cona, A. Involvement of polyamine oxidase in wound healing. Plant Physiol. 2008, 146, 162-177. [CrossRef]

17. Tavladoraki, P.; Cona, A.; Angelini, R. Copper-containing amine oxidases and FAD-dependent polyamine oxidases are key players in plant tissue differentiation and organ development. Front. Plant Sci. 2016, 7, 824-925. [CrossRef]

18. Wang, W.; Paschalidis, K.; Feng, J.-C.; Song, J.; Liu, J.-H. Polyamine catabolism in plants: A universal process with diverse functions. Front. Plant Sci. 2019, 10, 561. [CrossRef]

19. Planas-Portell, J.; Gallart, M.; Tiburcio, A.F.; Altabella, T. Copper-containing amine oxidases contribute to terminal polyamine oxidation in peroxisomes and apoplast of Arabidopsis thaliana. BMC Plant Biol. 2013, 13, 109. [CrossRef]

20. Fraudentali, I.; Ghuge, S.A.; Carucci, A.; Tavladoraki, P.; Angelini, R.; Rodrigues-Pousada, R.A.; Cona, A. Developmental, hormone- and stress-modulated expression profiles of four members of the Arabidopsis copper-amine oxidase gene family. Plant Physiol. Biochem. 2020, 147, 141-160. [CrossRef]

21. Fraudentali, I.; Ghuge, S.A.; Carucci, A.; Tavladoraki, P.; Angelini, R.; Cona, A.; Rodrigues-Pousada, R.A. The copper amine oxidase AtCuAO $\delta$ participates in abcisic acid-induced stomatal closure in Arabidopsis. Plants 2019, 8, 183. [CrossRef] [PubMed]

22. Moschou, P.N.; Sanmartin, M.; Andriopoulou, A.H.; Rojo, E.; Sanchez-Serrano, J.J.; Roubelakis-Angelakis, K.A. Bridging the gap between plant and mammalian polyamine catabolism: A novel peroxisomal polyamine oxidase responsible for a full back-conversion pathway in Arabidopsis. Plant Physiol. 2008, 147, 1845-1857. [CrossRef] [PubMed]

23. Rossi, F.R.; Gárriz, A.; Marina, M.; Pieckenstain, F.L. Modulation of polyamine metabolism in Arabidopsis thaliana by salicylic acid. Physiol. Plant. 2021, in press. [CrossRef] [PubMed]

24. Marina, M.; Sirera, F.V.; Rambla, J.L.; Gonzalez, M.E.; Blázquez, M.A.; Carbonell, J.; Pieckenstain, F.L.; Ruiz, O.A. Thermospermine catabolism increases Arabidopsis thaliana resistance to Pseudomonas viridiflava. J. Exp. Bot. 2013, 64, 1393-1402. [CrossRef]

25. Bordenave, C.D.; Granados-Mendoza, C.; Jiménez-Bremont, J.F.; Gárriz, A.; Rodríguez, A.A. Defining novel plant polyamine oxidase subfamilies through molecular modeling and sequence analysis. BMC Evol. Biol. 2019, 19, 28. [CrossRef]

26. Miyamoto, M.; Shimao, S.; Tong, W.; Motose, H.; Takahashi, T. Effect of thermospermine on the growth and expression of polyamine-related genes in rice seedlings. Plants 2019, 8, 269. [CrossRef]

27. Sagor, G.H.M.; Inoue, M.; Kusano, T.; Berberich, T. Expression profile of seven polyamine oxidase genes in rice (Oryza sativa) in response to abiotic stresses, phytohormones and polyamines. Physiol. Mol. Biol. Plants 2021, 27, 1353-1359. [CrossRef]

28. Upadhyay, R.K.; Fatima, T.; Handa, A.K.; Mattoo, A.K. Polyamines and their biosynthesis/catabolism genes are differentially modulated in response to heat versus cold stress in tomato leaves (Solanum lycopersicum L.). Cells 2020, 9, 1749. [CrossRef] 
29. Tong, W.; Imai, A.; Tabata, R.; Shigenobu, S.; Yamaguchi, K.; Yamada, M.; Hasebe, M.; Sawa, S.; Motose, H.; Takahashi, T. Polyamine resistance is increased by mutations in a nitrate transporter gene NRT1.3 (AtNPF6.4) in Arabidopsis thaliana. Front. Plant Sci. 2016, 7, 834. [CrossRef]

30. Hanzawa, Y.; Takahashi, T.; Komeda, Y. ACL5: An Arabidopsis gene required for internodal elongation after flowering. Plant J. 1997, 12, 863-874. [CrossRef]

31. Clough, S.J.; Bent, A.F. Floral dip: A simplified method for Agrobacterium-mediated transformation of Arabidopsis thaliana. Plant J. 1998, 16, 735-743. [CrossRef]

32. Jefferson, R.A.; Kavanagh, T.A.; Bevan, M.W. GUS fusions: Beta-glucuronidase as a sensitive and versatile gene fusion marker in higher plants. EMBO J. 1987, 6, 3901-3907. [CrossRef]

33. Tong, W.; Yoshimoto, K.; Kakehi, J.-I.; Motose, H.; Niitsu, M.; Takahashi, T. Thermospermine modulates expression of auxinrelated genes in Arabidopsis. Front. Plant Sci. 2014, 5, 94. [CrossRef]

34. Brownfield, D.L.; Todd, C.D.; Deyholos, M.K. Analysis of Arabidopsis arginase gene transcription patterns indicates specific biological functions for recently diverged paralogs. Plant Mol. Biol. 2008, 67, 429-440. [CrossRef]

35. Park, S.W.; Kaimoyo, E.; Kumar, D.; Mosher, S.; Klessig, D.F. Methyl salicylate is a critical mobile signal for plant systemic acquired resistance. Science 2007, 318, 113-116. [CrossRef] [PubMed]

36. Katayama, H.; Iwamoto, K.; Kariya, Y.; Asakawa, T.; Kan, T.; Fukuda, H.; Ohashi-Ito, K. A negative feedback loop controlling bHLH complexes is involved in vascular cell division and differentiation in the root apical meristem. Curr. Biol. 2015, 25, 3144-3150. [CrossRef]

37. Vera-Sirera, F.; De Rybel, B.; Úrbez, C.; Kouklas, E.; Pesquera, M.; Álvarez-Mahecha, J.C.; Minguet, E.G.; Tuominen, H.; Carbonell, J.; Borst, J.W.; et al. A bHLH-based feedback loop restricts vascular cell proliferation in plants. Dev. Cell 2015, 35, 432-443. [CrossRef]

38. Liu, C.; Atanasov, K.E.; Arafaty, N.; Murillo, E.; Tiburcio, A.F.; Zeier, J.; Alcázar, R. Putrescine elicits ROS-dependent activation of the salicylic acid pathway in Arabidopsis thaliana. Plant Cell Environ. 2020, 43, 2755-2768. [CrossRef] [PubMed]

39. Chang, K.S.; Lee, S.H.; Hwang, S.B.; Park, K.Y. Characterization and translational regulation of the arginine decarboxylase gene in carnation (Dianthus caryophyllus L.). Plant J. 2000, 24, 45-56. [CrossRef]

40. Hiragori, Y.; Takahashi, H.; Hayashi, N.; Sasaki, S.; Nakao, K.; Motomura, T.; Yamashita, Y.; Naito, S.; Onouchi, H. Genome-wide identification of Arabidopsis non-AUG-initiated upstream ORFs with evolutionarily conserved regulatory sequences that control protein expression levels. bioRxiv 2021. [CrossRef]

41. Hao, Y.; Huang, B.; Jia, D.; Mann, T.; Jiang, X.; Qiu, Y.; Niitsu, M.; Berberich, T.; Kusano, T.; Liu, T. Identification of seven polyamine oxidase genes in tomato (Solanum lycopersicum L.) and their expression profiles under physiological and various stress conditions. J. Plant Physiol. 2018, 228, 1-11. [CrossRef]

42. Guerrero-González, M.L.; Rodríguez-Kessler, M.; Jiménez-Bremont, J.F. uORF, a regulatory mechanism of the Arabidopsis polyamine oxidase 2. Mol. Biol. Rep. 2014, 41, 2427-2443. [CrossRef]

43. Guerrero-González, M.L.; Ortega-Amaro, M.A.; Juárez-Montiel, M.; Jiménez-Bremont, J.F. Arabidopsis Polyamine oxidase-2 uORF is required for downstream translational regulation. Plant Physiol. Biochem. 2016, 108, 381-390. [CrossRef]

44. Sagor, G.H.M.; Kusano, T.; Berberich, T. Identification of the actual coding region for polyamine oxidase 6 from rice (OsPAO6) and its partial characterization. Plant Signal. Behav. 2017, 12, e1359456. [CrossRef] [PubMed]

45. Wimalasekera, R.; Villar, C.; Begum, T.; Scherer, G.F. COPPER AMINE OXIDASE1 (CuAO1) of Arabidopsis thaliana contributes to abscisic acid- and polyamine-induced nitric oxide biosynthesis and abscisic acid signal transduction. Mol. Plant 2011, 4, 663-678. [CrossRef] [PubMed]

46. Cui, J.; Pottosin, I.; Lamade, E.; Tcherkez, G. What is the role of putrescine accumulated under potassium deficiency? Plant Cell Environ. 2020, 43, 1331-1347. [CrossRef] [PubMed]

47. Schraut, D.; Heilmeier, H.; Hartung, W. Radial transport of water and abscisic acid (ABA) in roots of Zea mays under conditions of nutrient deficiency. J. Exp. Bot. 2005, 56, 879-886. [CrossRef]

48. Réthoré, E.; Jing, L.; Ali, N.; Yvin, J.C.; Pluchon, S.; Hosseini, S.A. K deprivation modulates the primary metabolites and increases putrescine concentration in Brassica napus. Front. Plant. Sci. 2021, 12, 681895. [CrossRef]

49. Németh, M.; Janda, T.; Horvat, E.; Paldi, E.; Szalai, G. Exogenous salicylic acid increases polyamine content but may decrease drought tolerance in maize. Plant. Sci. 2002, 162, 569-574. [CrossRef]

50. Jang, E.-K.; Min, K.-H.; Kim, S.-H.; Nam, S.-H.; Zhang, S.; Kim, Y.C.; Cho, B.H.; Yang, K.-Y. Mitogen-activated protein kinase cascade in the signaling for polyamine biosynthesis in tobacco. Plant. Cell Physiol. 2009, 50, 658-664. [CrossRef]

51. Zhang, X.; Shen, L.; Li, F.; Meng, D.; Sheng, J. Methyl salicylate-induced arginine catabolism is associated with up-regulation of polyamine and nitric oxide levels and improves chilling tolerance in cherry tomato fruit. J. Agric. Food Chem. 2011, 59, 9351-9357. [CrossRef] [PubMed]

52. Lee, T.M.; Chu, C. Ethylene-induced polyamine accumulation in rice (Oryza sativa L.) coleoptiles. Plant. Physiol. 1992, 100, 238-245. [CrossRef] [PubMed]

53. Alcázar, R.; García-Martínez, J.L.; Cuevas, J.C.; Tiburcio, A.F.; Altabella, T. Overexpression of ADC2 in Arabidopsis induces dwarfism and late-flowering through GA deficiency. Plant. J. 2005, 43, 425-436. [CrossRef] [PubMed] 